\title{
Kemik ve yumuşak doku tümörlerinde biyopsi
}

\author{
Biopsy of bone and soft tissue tumors
}

\author{
Nevzat Dabak, Hasan Göçer, Alper Çıraklı
}

Ondokuz Mayıs Üniversitesi Tıp Fakültesi, Ortopedi ve Travmatoloji Anabilim Dalı, Samsun

\begin{abstract}
Klinik ve radyolojik incelemeyle kesin tanı konulamayan ve agresif görünümlü lezyonlarda tanıyı belirlemek için biyopsi yapılmalıdır. Malignite şüphesi olan lezyonlarda biyopsi, asıl tedavinin yapılacak olduğu merkezlerde yapılmalıdır. Ancak biyopsinin doğru yol göstermesi için klinik ve radyolojik veriler multidisipliner olarak konseylerde değerlendirilmelidir. Biyopsi tekniği ve lokalizasyonu iyi planlanmalı, patolog yapılan işlemin her aşamasından haberdar olmalıdır. Başarılı bir biyopsi; lezyonla, hekimle, fiziksel imkanlarla ve patoloğun birikimiyle doğrudan ilişkilidir.
\end{abstract}

Anahtar sözcükler: kemik tümörleri; yumuşak doku tümörleri; biyopsi

\begin{abstract}
Biopsy is essential for the assessment of aggressive-looking bone and soft tissue tumors if accurate diagnosis is not possible by clinical and radiological examinations. Biopsy of the suspected malignant lesions should be performed in the main treatment centers. However, for the right to guide of the biopsy, the clinical and radiological data should be evaluated by a multidisciplinary council. The technique and localization of the biopsy must be well planned, and pathology physician should be informed at each step. A successful biopsy is closely related to the type of lesion, physical facilities and the expertise of the physician.
\end{abstract}

Key words: bone neoplasms; soft tissue neoplasms; biopsy
B iyopsi kemik ve yumuşak doku tümörlerinde tanı ve tedavinin temelini oluşturur. Biyopsi genel olarak basit ve kolay bir işlem gibi görünse de, sonrasında tedavi sürecini önemli ölçüde etkilediğinden, hafife alınmamalıdır. Özellikle malign kemik tümörleri ve yumuşak doku sarkomlarının başarılı tedavisi için iyi planlanmış bir biyopsi şarttır. Gereksiz, yanlış teknik veya insizyonla yapılmış biyopsilerden kaçınılmalıdır (Şekil 1). Uygun olmayan biyopsi tedaviye yarardan daha çok zarar vereceğinden temel eğitimin alınmış olması veya asıl tedaviyi üstlenecek merkezlerde yapılması şarttır. ${ }^{[1,2]}$ Multidisipliner yaklaşım olmadan verilmiş biyopsi kararı bazen gereksiz yere bazen de yanlış yerden örnek alınmasına neden olabilir. Asıl tedavide kullanılacak insizyonun dışında bir insizyon kullanılması ya da alınmış örneği değerlendiren patoloji uzmanına doğru klinik bilgi verilmemesi, dönüşü olmayan hatalara yol açabilir. Tespit edilen lezyonun benign, malign veya metastatik bir kemik lezyonu olabileceği unutulmamalıdır. Özellikle onkolojik radyoloji deneyimi olmayan ve hasta yoğunluğu olan merkezlerde hazırlanmış raporlara veya sadece görüntüleme raporlarına bakılarak tanı veya tedavi amaçlı cerrahi girişimde bulunulmamalıdır. Hastaların malign lezyon şüphesi olması halinde, biyopsi öncesinde ilgili merkezlere yönlendirilmesi en doğru tercih olacaktır. Kemik ve yumuşak doku tümörlerinin çoğu benign lezyonlar olması nedeniyle bazen takip bazen de doğrudan cerrahi olarak çıkarılabilir. ${ }^{[3]}$

Bu kararı verirken hastanın fizik muayenesi yapılmalı ve ileri görüntüleme yöntemleri kullanılmalıdır. Öncelikle hastanın öyküsü alınmalıdır. Lezyonun büyüme hızı, ağrısı, nörolojik semptomlar, diğer dokularla ilişkisi, derinliği ve hareketliliği değerlendirilmelidir. Klinik şüphelere göre laboratuvar tetkikleri ve radyografik incelemeler yapılmalıdır. ${ }^{[4]}$ Radyolojik tetkikler direkt grafi, ultrasonografi (US), bilgisayarlı tomografi (BT), manyetik rezonans (MR) görüntüleme ve kemik sintigrafisi ile lezyonun olası ön tanısı, malign olup olmadığı ortaya konulmaya çalışılır. Bu tetkikler

- İletişim adresi: Prof. Dr. Nevzat Dabak, Ondokuz Mayıs Üniversitesi Tıp Fakültesi, Ortopedi ve Travmatoloji Anabilim Dalı, Kurupelit-Atakum, Samsun Tel: 0532 - 2832748 e-posta: ndabak@gmail.com

- Geliș tarihi: 17 Haziran 2014 Kabul tarihi: 17 Haziran 2014 

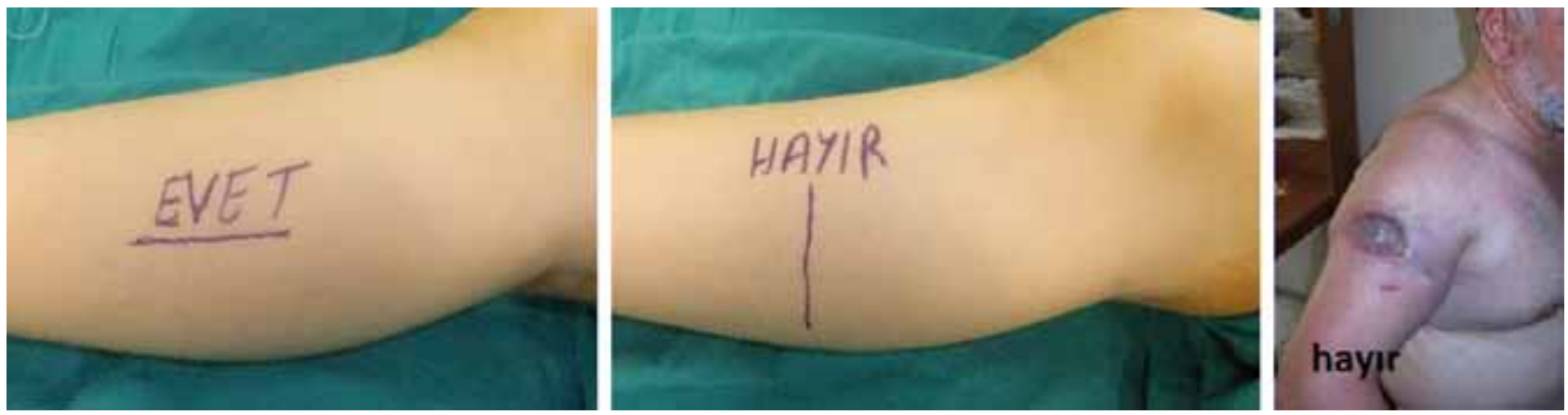

Şekil 1. Doğru ve yanlış biyopsi örnekleri.

tamamlanmadan biyopsi yapılmamalıdır. Biyopsi sonrası yapılacak radyolojik incelemeler hatalı yorumlara neden olacaktır.

Bu bulgular, onkolojiyle uğraşan ortopedi, radyoloji, patoloji, nükleer tıp, radyasyon onkolojisi ve medikal onkoloji uzmanlarının yer aldığı konseyce değerlendirilmelidir. Multidisipliner yaklaşımla öncelikle lezyonun tümör veya benzeri bir lezyon mu, yoksa travma, metabolik bir hastalık, kemiğin vasküler hastalığı veya enfeksiyon mu olduğu değerlendirilmelidir. Bu değerlendirme sonrası birçok kemik ve yumuşak doku tümörü tanısı konulabilmekte, tümörün evrelemesi yapılabilmektedir. Bazılarında (nonossifiye fibroma) sadece takip yapılırken, bir kısmında (osteoid osteoma) cerrahi tedavi planlanabilir.

Tanısı kesin olmayan ve malign şüphesi olan agresif görünümlü lezyonlarda biyopsi planlanmalıdır. Planlamada kapalı veya açık biyopsi yönteminin tercihi yapılmalıdır. Biyopsi yerinin asıl cerrahi tedavide çıkarılacak hat üstünde olması ve en canlı dokulardan örnek alınması gerekir. Biyopsiyi yapan cerrah, asıl tedavide ampütasyon veya ekstremite koruyucu cerrahide kullanılacak insizyon hatlarını göz önüne alarak plan yapmalıdır.

Patolojik dokuyu inceleyecek patoloji uzmanı, tümör konseyinin öngörüleri hakkında bilgisi olması halinde ayırıcı tanıda daha hızlı ve doğru değerlendirme yapar.

\section{BIYOPSI YÖNTEMLERi}

Biyopsiler genel olarak kapalı ve açık biyopsiler olmak üzere iki grupta toplanır. Her birinin bazı yönlerden avantaj ve dezavantajları vardır. ${ }^{[5,6]}$ Ortopedik onkolojiyle uğraşan hekim, mevcut bilgi ve birikimlerini kullanarak, hangi yöntemin hangi durumlarda daha üstün olduğunu bilmelidir. Hangi biyopsi yönteminin tercih edileceği, lezyonun muhtemel tanısı, anatomik lokalizasyonu, hastayla olan iletişim, çalışılan hastanenin olanakları, materyali değerlendirecek patoloğun deneyim ve tercihine göre değişebilir.

\section{Kapalı biyopsi}

İnce iğne aspirasyon biyopsisi (fine needle aspiration) ve kalın iğne biyopsisi (tru-cut iğneleri, Jamshidi iğneleri) şeklinde yapılabilir. Tru-cut veya Jamshidi biyopsi iğneleri ile alınan örnekler bir petri kutusunda serum fizyolojik ile ıslatılmış spançlı lam üzerinde gönderilir (Şekil 2).

İnce iğne (0-7 mm çaplı) aspirasyon biyopsisi; sınırlı doku alınabildiğinden genellikle daha önce tanısı konmuş tümörlerin lokal nüks ve lenf nodu tutulumunu saptamak için kullanılır. Deneyimli merkezlerde ince iğne aspirasyon biyopsisi ile yeterli örnekleme aspire edildiğinde hücre düzeyinde $\% 80-90$ arasında doğru tanı konulur. Ancak, bu yöntem evreleme ve spesifik tümör tanımlamalarında yetersizdir. ${ }^{[7]}$

Tru-cut iğne biyopsisi; kanüllü trokarlı bir iğne ile biyopsidir. Yüzeyel yumuşak doku kitlelerinde, yumuşak doku bileşkesi olan kemik lezyonlarında tru-cut iğne biyopsisi tercih edilir. Bunun için özel üretilmiş otomatik ve yarı otomatik, farklı kalınlıklarda biyopsi iğneleri bulunmaktadır (Şekil 2). Doğru tanı \%90-95 oranında konulabilir. ${ }^{[8]}$

Jamshidi iğne; kanüllü trokarlı iğneden oluşmakta olup sert kemik dokusundan örnek alımında kullanılır (Şekil 3). Uygulaması ve başarısı diğerlerinden daha zor ve zahmetlidir.

Kapalı biyopsi, poliklinik şartlarında lokal anestezi altında cilde sadece bir iğne deliği kadar yerden girilerek yapılabilir. Hastanın hastanede yatmasına gerek kalmaz, ameliyathane hazırlıklarına ve zaman kaybına neden olmaz. Tümör hücrelerinin çevre yumuşak dokulara yayılması, enfeksiyon, hematom, yaranın iyileşmeme ve patolojik kırık riskleri en düşüktür. ${ }^{[5,9]}$ Hızlı büyüyen ve ekspansiyon yapan tümörlerin insizyon 

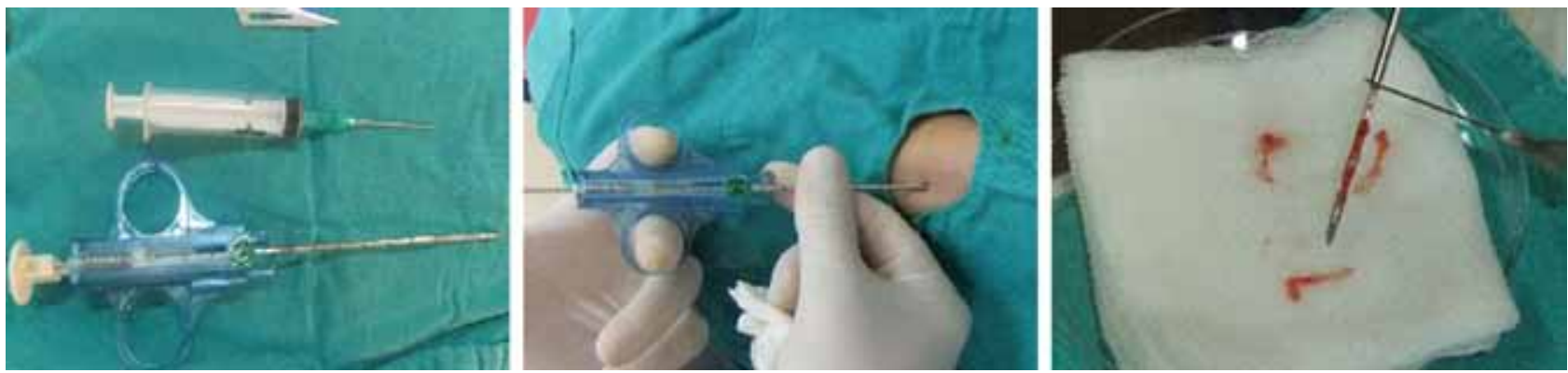

Şekil 2. Tru-cut biyopsi iğnesi ve uygulaması; doku örneğinin konduğu ıslak petri kutusu.
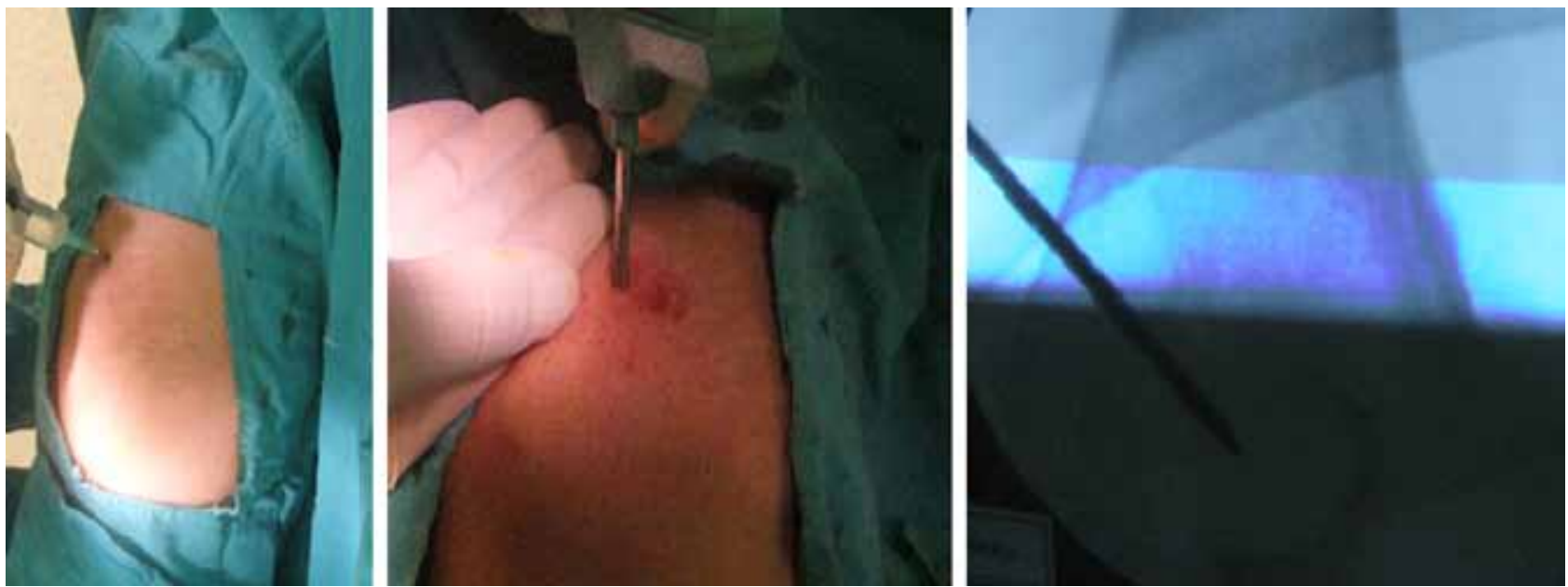

Şekil 3. Femur distal yerleşimli lezyonda lokal anestezi yapılarak Jamshidi ile skopi eşliğinde biyopsi uygulaması.
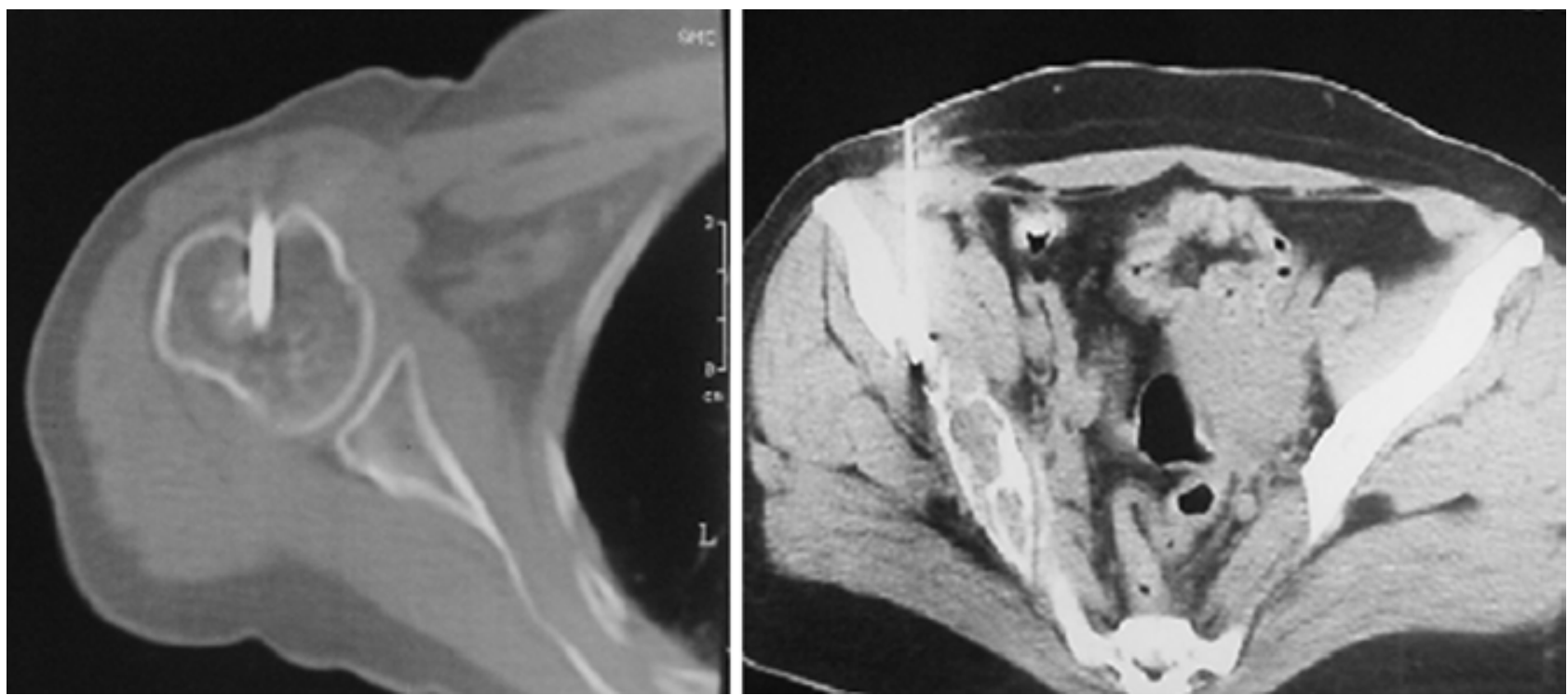

Şekil 4. BT eşliğinde biyopsi yapılması.

problemlerinden kaynaklanan yara iyileşme sorunlarından kaçınmayı sağlar. Palpe edilen yumuşak doku komponenti olan lezyonlarda yardımcı görüntüleme yöntemleri kullanılmadan başarılı bir şekilde yapılabilir. ${ }^{[2]}$ Ulaşılması zor olan bölgelere (pelvis, vertebra) $B T, M R$ ve US eşliğinde ulaşma olanağı sağlar (Şekil 4). ${ }^{[10-12]}$ Metastatik lezyon, enfeksiyon ve lokal nüks olan tümörlerde doğruluğu en yüksek iken, 
heterojen içeriğe sahip lezyonlarda yanıltıcı negatif sonuç elde edilebilir. Radyoterapi yapılması gereken olgularda beklemeye gereksinim kalmaz.

Kapalı biyopsilerinin en büyük dezavantajı küçük boyutlarda örnek alınmasıdır. Yeterli örnek alabilmek için aynı delikten fakat farklı bölgelerden birden fazla örnek alınmalıdır. Bu da deneyimli olmayan cerrahlar tarafindan yapılması halinde derinlere girilerek oradaki sağlam dokulara tümörün yayılmasına veya nörovasküler hasarların oluşmasına neden olabilir. ${ }^{[13]}$ Büyük lezyonlarda biyopsinin nekrotik bölgeden alınması tanıyı tamamen hatalı yapabilir. Bu yöntemde tümör hücrelerinin görülmesi ile tanı konulurken, görülmemesi tümör varlığını ekarte etmez. Yeterli örnekleme olmayan olgularda biyopsi tekrarı veya açık biyopsi gerekebilir. ${ }^{[14]}$ Alınan materyalin az olması nedeniyle bazen immünohistokimyasal, elektron mikroskopisi, moleküler genetik çalışmalar, histolojik alt tipleme veya evreleme yapılamayabilir. Deneyimi az olan merkezlerde tekrarlanması gereken incelemeler için materyal olmaması tanının ve tedavinin gecikmesine neden olabilir. Radyoloji uzmanı tarafından BT veya US eşliğinde yapılan kapalı biyopsiler doğru yerden doku alınmasını kolaylaştırır. Ancak, uzman tedavide uygulanacak insizyon hattı konusunda bilgilendirilmelidir. Biyopsi yeri muhakkak işaretlenmeli ve hastanın dosyasına not edilmelidir.

Alınan örnek, kas-iskelet tümörleri konusunda deneyimli patoloji uzmanı tarafından incelenmelidir. Klinik bilgi ve radyolojik incelemeler ve varsa tümör konseyinin yorumu patoloji uzmanıyla önceden paylaşılmalıdır.

\section{Açık biyopsi}

Kas-iskelet sistemi lezyonlarının büyük bir kısmında, iyi planlanan ve deneyimli ekiplerce biyopsi yapılması halinde doğru tanı konulabilir. Açı biyopsinin deneyimsiz bir cerrah tarafindan yapılması teknik olarak zordur ve tümör hücrelerinin sağlıklı dokulara bulaşmasına neden olabilir. Deneyimsiz bir patoloji uzmanı içinse, daha fazla doku örneği alınması, daha ayrıntılı ve tekrarlayan çalışmalar yapılmasından dolayı yanılma payını azaltır. Kapalı biyopsi teknikleriyle kıyaslanırsa, lezyon hakkında daha doğru ve ayrıntılı histopatolojik bilgi elde edilebilir. Açık biyopsilerin başlıca sakıncaları ise artmış kontaminasyon, hematom, enfeksiyon ve patolojik kırık oluşabilmesidir. ${ }^{[15]}$

Açık biyopsiler; insizyonel, eksizyonel ve frozen olarak yapılabilir.

İnsizyonel biyopsi; tüm lezyonu eksize etmeden, içinden yeterli miktarda doku alınmasına denir. Bu işlem sırasında cerrah tarafindan veya aletlerle dokunulan tüm bölgeler muhtemel tümör hücreleri tarafindan kontamine edilmiş sayılmalıdır. Eksizyonel biyopsiye göre sağlam dokulara tümör yayılım riski daha azdır. Genellikle malign kemik tümörü ve yumuşak doku sarkomu şüphesi olanlarda yapılır. Kapalı biyopsi başarısızlığında, lezyonun sert ve ossifiye olduğu durumlarda, histolojik ve radyolojik olarak zor olgularda ve büyük lezyonlarda tercih edilir. ${ }^{[16]}$ Biyopsi öncesi radyolojik incelemeler yapılarak, doku örneği canlı tümör dokusundan zengin olan bölgeden alınmaya çalışılmalıdır (Şekil 5).

Eksizyonel biyopsi; klinik ve radyolojik olarak sınırları net ortaya konmuş, tanıda şüphe olmayan durumlarda lezyonun içine girilmeden çevresindeki kapsülle birlikte tamamıyla çıkarılması işlemine denir. Bu işleme aynı zamanda marjinal eksizyon da denir. Kemik ve yumuşak doku tümörlerinde klinik ve radyolojik olarak benign lezyon olduğundan emin olunduğu durumlarda yapılabilir. ${ }^{[17]}$ Böylece tek cerrahi işlemle tanı ve tedavi yapılmış olur (Şekil 6). Ancak bu yöntemi tercih ederken multidisipliner yaklaşılmalıdır. Malign lezyonda
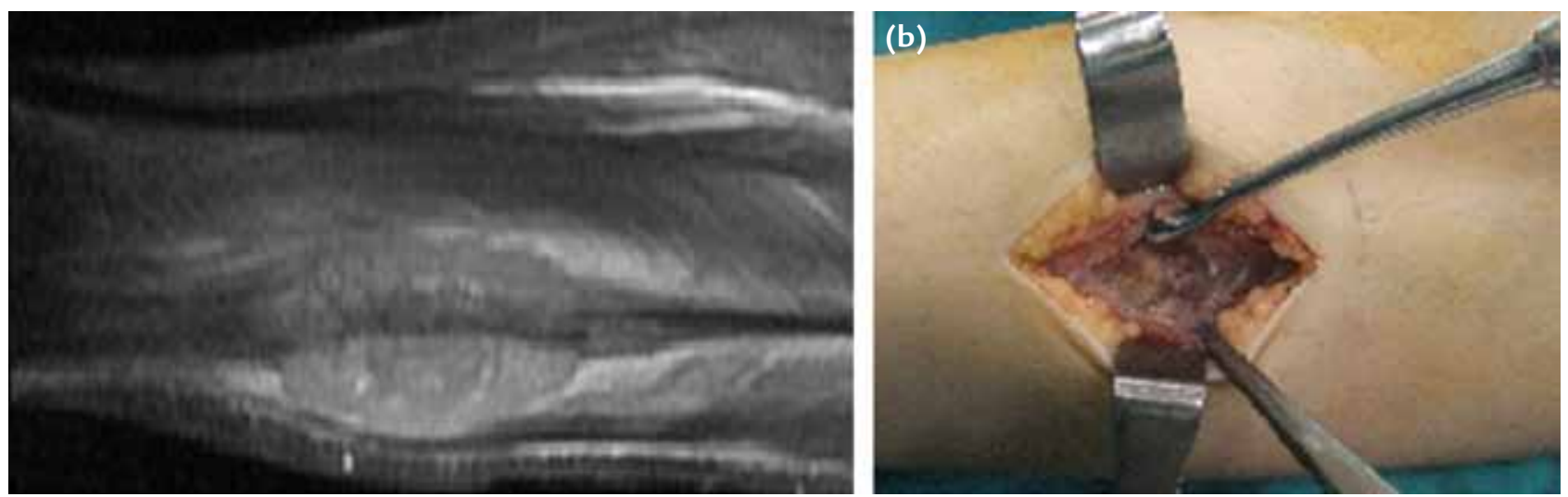

Şekil 5. a, b. Fibula yerleşimli lezyonun MR görüntüleme (a) ve açık biyopsi (b) görünümü. 

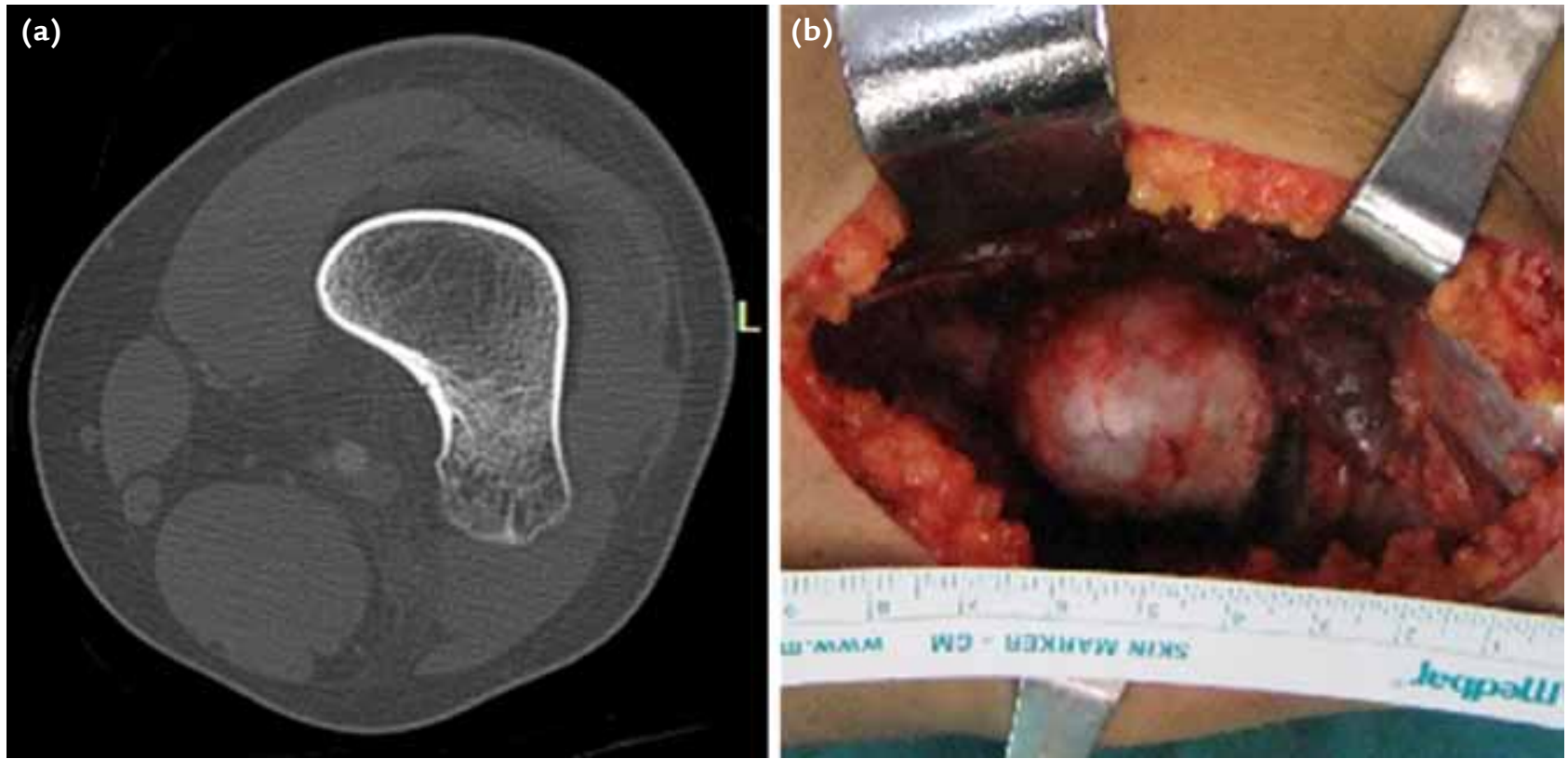

Şekil 6. a, b. Femur distal yerleşimli osteokondromun radyolojik (a) ve ameliyat sırasındaki (b) görünümü.

yapılacak böyle bir planlama tüm çevrenin kontaminasyonuna ve belki de korunabilecek bir ekstremitenin, hatta yaşam kaybına neden olacaktır. ${ }^{[1]}$

Frozen biyopsi; klinik ve radyolojik veriler değerlendirilerek ameliyat esnasında tanıyı kesinleştirilip, tek seansta asıl tedaviyi de yapmaya olanak vermesi nedeniyle, bazen de tanısı belli olan hastalarda cerrahi sınırın güvenilirliğini doğrulamak için tercih edilir. ${ }^{[5]}$ Genel durumu ikinci cerrahi müdahaleye izin vermeyecek hastalarda, risk paylaşımı yapılarak tercih edilebilir. Ancak biyopsiyi yapan cerrah ile dokuyu inceleyecek patoloji uzmanı, çok deneyimli olmanın yanı sıra yanılabilecekleri noktaları bilerek kendi aralarında iletişim halinde olmalıdırlar. Örnek olarak enkondromkondrosarkom ayrımın frozen inceleme ile yapmak neredeyse imkansızdır. Histolojik tanı ve derecelendirmeden ziyade daha genel hatlariyla, enfeksiyon, benign, malign veya metastatik tümör olup olmadığı konusunda yararlanılabilir. ${ }^{[6]}$ Yumuşak doku tümörlerinde daha çok yararlıdır. Malign kemik tümörü ve yumuşak doku sarkomlarında tanı hatalarından dolayı tercih edilmemelidir. Patolojik incelemede kesin tanı konulamıyor ve şüphe varsa, asıl cerrahi tedavi ikinci seansa bırakılmalıdır. Patolojik tanıdan emin olunduğu takdirde, aynı anda asıl cerrahi tedavi uygulanabilir. Bunun için biyopsi hattı kapatılıp yeni set ve yeni örtünme ile cerrahi uygulanmalıdır.

Açık biyopside dikkat edilecek genel kurallar şunlardır: Turnike venöz stazı ve embolizasyonu arttırdığı için kullanılmamalıdır; kullanılacaksa bandaj sarılmamalıdır. Ekstremitede transvers insizyon yapılmamalıdır. Biyopsi giriş yeri bir kompartmanı ya da eklemi transvers geçmemelidir. ${ }^{[18]}$ İnsizyon hattı majör nörovasküler oluşumlardan uzak olmalıdır. Standart ortopedik cerrahi girişim yerlerinden ziyade en kısa yoldan lezyona ulaşma hedeflenmelidir. Asıl cerrahi tedavide kullanılacak insizyon hatları dikkate alınmalıdır.

Biyopsi esnasında kullanılacak aletler masada aynı yönde bekletilmeli, aynı yönüyle ekartasyon sağlanmalı, cerrah veya asistanlar cerrahi bölgeye elleriyle müdahale etmeyip olabildiğince aynı aletlerle çalışmalıdırlar. Böylece kontaminasyon olasılığı en aza indirilmiş olur. Alınan örnekler nekroz alanından alınmamalıdır. ${ }^{[19]}$ Yumuşak dokudan örnek alınırken kas fasyaları arasından değil, doğrudan kas içinden girilerek tek kompartman içinde çalışılmalıdır. Lezyon kemik içinde ise, korteksin en zayıf olduğu yerden kapak açılmalıdır. Kemikten biyopsi alınırken patolojik kırık gelişmemesi için sirküler kapak açılmalıdır. ${ }^{[20]} \mathrm{Bu}$ işlem sirküler testereler ile yapılmalıdır (Şekil 7). Kemikten alınan örneklerin metafizden yapılması tercih edilmelidir (torsiyonel stresi azaltmak için).

Reaktif kemik oluşumundan dolayı Codman üçgeni veya kırık sahasından, malign lezyonları taklit ettiğinden, örnek alınmamalıdır. Enfeksiyon ihtimali de düşünülerek işlem öncesinde antibiyotik verilmeden, mikrobiyolojik inceleme için de doku örneği alınmalıdır. Radyoterapi almış veya daha önce biyopsi yapılmış 

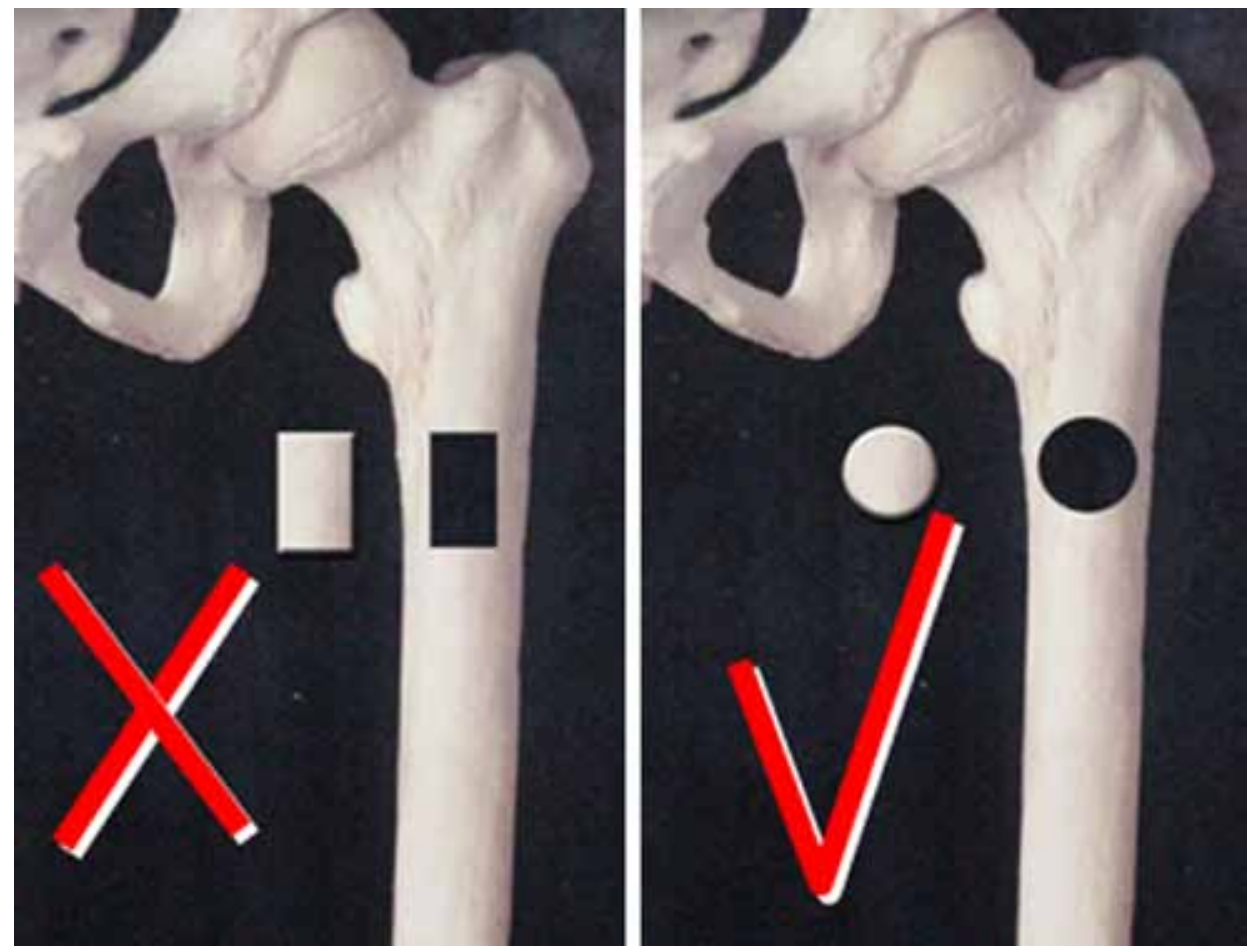

Şekil 7. Kemik biyopsisinde kapak açılması.
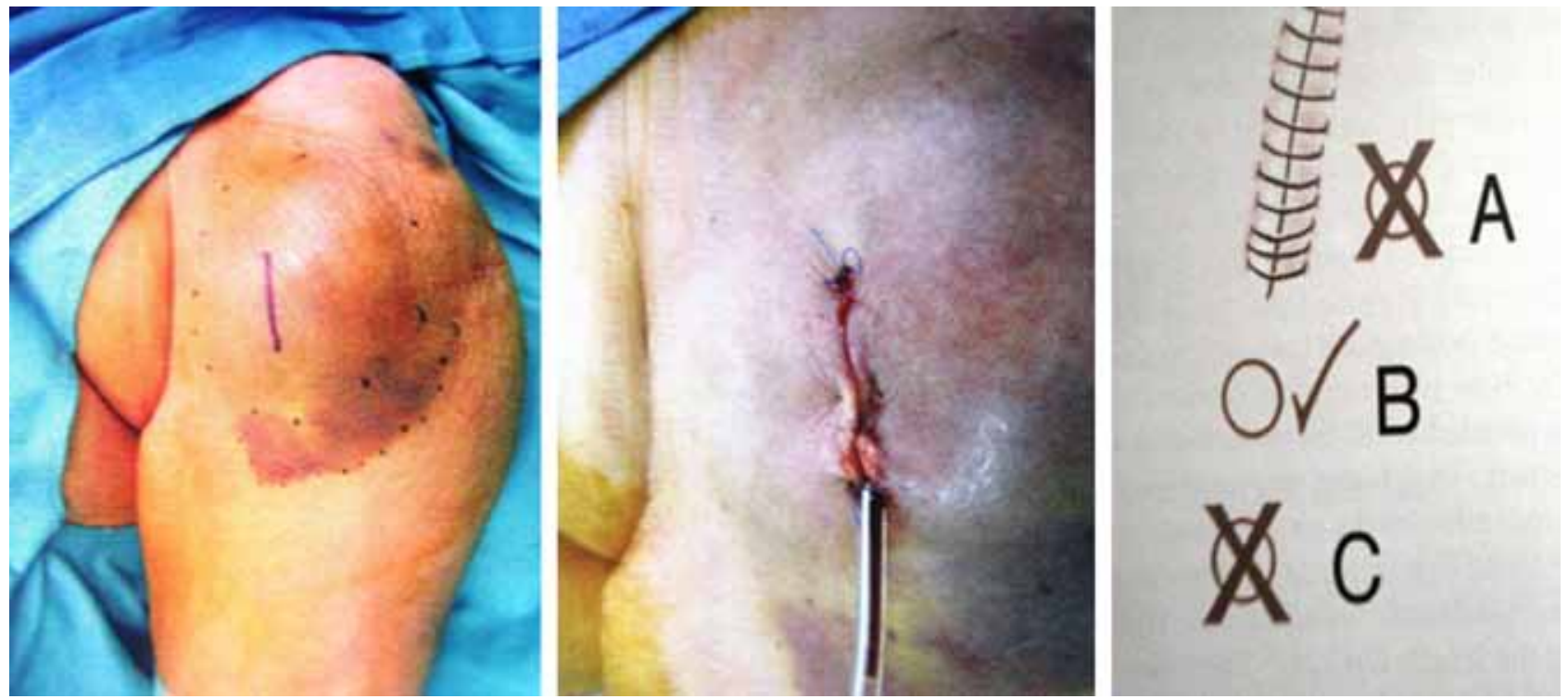

Şekil 8. İnsizyon hattı ve drenin çıkış hattı.

alanlardan kaçınılmalıdır. Kemikte açılan pencereler metil metakrilat veya kemik mumu ile kapatılmalıdır. Dren, insizyon yerinden veya insizyon hattının yakın bir yerinden ve aynı kompartmandan geçirilerek konulmalıdır (Şekil 8). İşlem bittikten sonra turnike kullanılmışsa açılmalı ve kanama kontrolü çok iyi yapıldıktan sonra dikkatli bir şekilde yara kapatılmalıdır.
Sonuç olarak, klinik, laboratuvar ve radyolojik veriler multidisipliner deneyimli ekiplerce doğru değerlendirilirse kemik ve yumuşak doku lezyonlarının büyük bir kısmında tanı koymak ve uygun tedaviyi planlamak mümkündür. Ancak klinik ve radyolojik bulgularda agresif görünümler varsa, iyi planlanmış biyopsi yöntemi ile kesin tanı konulabilecek ve en uygun tedavi uygulanabilecektir. 


\section{KAYNAKLAR}

1. Mankin HJ, Lange TA, Spanier SS. The hazards of biopsy in patients with malignant primary bone and soft-tissue tumors. J Bone Joint Surg Am 1982;64(8):1121-7.

2. Joshi A, Magar SR, Chand P, Panth R, Khatri Chhetri BR. Tru-cut biopsy as the initial method of tissue diagnosis in bone tumors with soft tissue extension. Indian J Orthop 2013;47(2):195-9. CrossRef

3. Lehotska V. Soft-tissue tumors--role of diagnostic imaging. Bratisl Lek Listy 2005;106(6-7):236-7.

4. Le HB, Lee ST, Munk PL. Image-guided musculoskeletal biopsies. Semin Intervent Radiol 2010;27(2):191-8. CrossRef

5. Ray-Coquard I, Ranchére-Vince $D$, Thiesse $P$, Ghesquières $H$, Biron P, Sunyach MP, Rivoire M, Lancry L, Méeus P, Sebban $C$, Blay JY. Evaluation of core needle biopsy as a substitute to open biopsy in the diagnosis of soft-tissue masses. Eur J Cancer 2003;39(14):2021-5.

6. Kasraeian S, Allison DC, Ahlmann ER, Fedenko AN, Menendez LR. A comparison of fine-needle aspiration, core biopsy, and surgical biopsy in the diagnosis of extremity soft tissue masses. Clin Orthop Relat Res 2010;468(11):2992-3002. CrossRef

7. Yang YJ, Damron TA. Comparison of needle core biopsy and fine-needle aspiration for diagnostic accuracy in musculoskeletal lesions. Arch Pathol Lab Med 2004;128(7):759-64.

8. Kissin MW, Fisher C, Carter RL, Horton LW, Westbury G. Value of Tru-cut biopsy in the diagnosis of soft tissue tumors. Br J Surg 1986;73(9):742-4.

9. Olscamp A, Rollins J, Tao SS, Ebraheim NA. Complications of CT-guided biopsy of the spine and sacrum. Orthopedics 1997;20(12):1149-52.

10. Saifuddin A, Mitchell R, Burnett SJS, Sandison A, Pringle JA. Ultrasound-guided needle biopsy of primary bone tumors. J Bone Joint Surg Br 2000;82(1):50-4.
11. Tsukushi S, Katagiri $H$, Nakashima H, Shido $Y$, Arai E. Application and utility of computed tomography-guided needle biopsy with musculoskeletal lesions. J Orthop Sci 2004;9(2):122-5.

12. Carrino JA, Khurana B, Ready JE, Silverman SG, Winalski CS. Magnetic resonance imaging-guided percutaneous biopsy of musculoskeletal lesions. J Bone Joint Surg Am 2007;89(10):2179-87.

13. Olscamp A, Rollins J, Tao SS, Ebraheim NA. Complications of CT-guided biopsy of the spine and sacrum. Orthopedics 1997;20(12):1149-52.

14. Liu JC, Chiou HJ, Chen WM, Chou YH, Chen TE, Chen W, Yen CC, Chiu SY, Chang CY. Sonographically guided core needle biopsy of soft tissue neoplasms. J Clin Ultrasound 2004;32(6):294-8.

15. Davies NM, Livesley PJ, Cannon SR. Recurrence of an osteosarcoma in a needle biopsy track. J Bone Joint Surg Br 1993;75(6):977-8.

16. Rydholm A, Alvegård $T$, Berg NO, Dawiskiba Z, Eqund $\mathrm{N}$, Idvall I, Petersson $\mathrm{H}$, Rööser $\mathrm{B}$, Willén $\mathrm{H}$, Akerman $\mathrm{M}$. Preoperative diagnosis of soft tissue tumours. Int Orthop 1988;12(2):109-14.

17. Pohlig F, Kirchhoff C, Lenze U, Schauwecker J, Burqkart R, Rechl $\mathrm{H}$, von Eisenhart-Rothe R. Percutaneous core needle biopsy versus open biopsy in diagnostics of bone and soft tissue sarcoma: a retrospective study. Eur J Med Res 2012;17:29. CrossRef

18. Bickels J, Jelinek JS, Shmookler BM, Neff RS, Malawer MM. Biopsy of musculoskeletal tumors. Current concepts. Clin Orthop Relat Res 1999;(368):212-9.

19. Ng VY, Thomas K, Crist M, Wakely PE Jr, Mayerson J. Fine needle aspiration for clinical triage of extremity soft tissue masses. Clin Orthop Relat Res 2010;468(4):1120-8. CrossRef

20. Clark CR, Morgan C, Sonstegard DA, Mathews LS. The effect of biopsy-hole shape and size on bone strength. J Bone Joint Surg Am 1977;59(2):213-7. 